\title{
Abundance of Culturable Bacteria Isolated from Maize Rhizosphere Soil Using Four Different Culture Media
}

\author{
ERNIN HIDAYATI ${ }^{1,3}$, ARIS TRI WAHYUDI ${ }^{1}$ *, ANTONIUS SUWANTO ${ }^{1}$, \\ AND RAHAYU WIDYASTUTI ${ }^{2}$
}

\author{
${ }^{1}$ Department of Biology, Faculty of Mathematics and Natural Sciences, \\ Institut Pertanian Bogor, Bogor 16680, Indonesia; \\ ${ }^{2}$ Department of Soil Science and Land Resources, Faculty of Agriculture, \\ Institut Pertanian Bogor, Bogor 16680, Indonesia; \\ ${ }^{3}$ Department of Biology, Faculty of Mathematics and Natural Science, \\ Universitas Mataram, West Lombok 83125. Indonesia
}

\begin{abstract}
Composition and abundance of culturable bacteria of four soil samples (Ktr50II, D50II, G50II, and A50II) were analyzed. The soil samples were collected from maize rhizosphere that planted in dryland Lombok Island. Each soil sample give different growth performance of maize in greenhouse experiment. This study was to investigate the relation of maize growth performance with culturable bacterial community of their rhizosphere and the effect of culture media on number of bacterial isolates recovery. The rhizosphere bacteria were cultured and isolated on commercial media (SEA) and non commercial modification media (NAln, NAln-SE and NAlnRE). Thirty four strains rhizosphere bacteria were obtained from four maize rhizophere soil samples. D50II is the soil sample that caused the better growth performance to the maize, contrary to Ktr50II. D50II has significantly highest number of culturable bacterial types, while significantly lowest on Ktr50II. In D50II, at least 17 bacterial isolates contributed to better growth performance in maize and have relative abundance of dominant isolate not more than $35.34 \%$. In comparing the rhizosphere bacteria recovered using different culture media, bacteria cultivated on SEA have different growth characteristic compared with bacteria cultivated on NAln, NAln SE and NAln-RE. Six bacterial isolates showed antagonistic ability when grew on SEA but not in all of three media. Compared with commercial media, non commercial modification media can increase total isolates recovery about $70.6 \%$.
\end{abstract}

Key words: culture media, dryland, maize, rhizosphere bacteria

Telah dilakukan kajian komposisi dan kelimpahan bakteri terkultur dari empat sampel tanah (Ktr50II, D50II, G50II, dan A50II). Sampel tanah dikoleksi dari rizosfer tanaman jagung yang tumbuh di lahan kering Pulau Lombok. Pada penelitian skala rumah kaca diketahui bahwa setiap sampel tanah memberikan performa pertumbuhan berbeda pada tanaman jagung. Penelitian ini bertujuan untuk mengetahui hubungan antara performa pertumbuhan tanaman jagung dengan komunitas bakteri terkultur penghuni daerah perakarannya serta pengaruh media kultur terhadap perolehan isolat bakteri. Bakteri rizosfer di kultur dan diisolasi menggunakan media komersil (SEA) dan media modifikasi non komersil (Naln, NAln-SE and NAln-RE). Sebanyak 34 isolat bakteri diperoleh dari keempat sampel tanah. D50II diketahui memberikan performa pertumbuhan yang lebih baik pada tanaman jagung, sebaliknya Ktr50II memberikan performa pertumbuhan yang buruk. D50II mempunyai jumlah jenis bakteri terkultur paling banyak dan sebaliknya pada Ktr50II. Pada D50II, sedikitnya 17 isolat bakteri terlibat dalam menghasilkan pertumbuhan yang lebih baik pada tanaman jagung, serta dengan jumlah kelimpahan relatif isolat dominan tidak lebih dari 35,34\%. Bila membandingkan bakteri rizosfer yang diperoleh dengan media kultur berbeda, terlihat bahwa bakteri yang terkultivasi pada SEA mempunyai karakter pertumbuhan yang berbeda dibandingkan bakteri yang terkultivasi pada NAln, Naln-SE and NAln-RE. Enam isolat bakteri menunjukkan kemampuan antagonis saat tumbuh pada SEA, namun kemampuan tersebut tidak muncul saat tumbuh pada tiga media lainnya. Dengan media modifikasi non komersil dapat meningkatkan perolehan isolat sekitar 70,6\% dibandingkan hanya menggunakan media komersial.

Kata kunci: bakteri rizosfer, lahan kering, media kultur, tanaman jagung

Indonesia has marginal land, such as dryland, swamp, swampy, tides and peat. However, they are not utilized optimally (RENSTRA the Ministry of Agriculture 2009). Based on wide area, ecological

*Corresponding author; Phone/Fax: +62-251-8622833, Email: aristri2011@gmail.com potency, social and economic potency, dryland is appropriated to optimize. West Nusa Tenggara (NTB) is one of the provinces in Indonesia with a relatively wide dryland. From the total area (about 1673476.307 ha in Lombok and Sumbawa Islands), only about 626034.60 ha that can be developed (BAPPEDA NTB 
2003). Now, the dryland is being actively used primarily for maize plantation.

Soil microbes have a significant role in the soil ecosystem. So that they can be used as a selective indicator of soil and also as the main index to evaluate the soil quality and global diversity (Zhang et al. 2013). Therefore, soil microbe are feasible for fundamental components that could be considered as one of the management strategies for sustainable agriculture in dryland. Soil microbial communities can be influenced by many factors. Several studies showed that rhizosphere bacterial communities of maize influenced by complex interaction, such as soil type (Castellanos et al. 2009), plant growth stage (Di Cello et al. 1997), cultivar (Dohrmann et al. 2013) and genotype (Schmalenberger and Tebbe 2003). Although growing on the same soil type, same species and age of plant, sometimes individually of maize has a different growth performance. This case has not been ever studied yet, especially in dryland Lombok Island. According to $\mathrm{Li}$ et al. (2014), rhizosphere bacteria have significant contribution to crop health, productivity and carbon sequestration. Thus it is predicted that the difference of plant growth performances have relation to rhizosphere bacterial community of that plant.

Rhizosphere bacterial communities have been analyzed using cultivation technique and metagenome. Although many molecular techniques used to study many aspects of environmenal microbe, but this technique has disadvantage, such as inavailability of culture isolates. As a result, it is impossible to study some aspects related to the life and function of the isolates. Cultivation technique have significantly contributed to our understanding of living microbes (Pham and Kim 2012). Until now, cultivation technique is fundamental tool to provide access to diverse characteristics and physiology of microbe (Reid and Buckley 2011). Culture isolates obtained can be stored for further analysis and application. Cultivation technique is also not expensive relatively. This method can be applied by many laboratories, including laboratories in developing countries. Because of this technique has been done since long time ago, so that the results of this technique has been well documented that could be useful for comparison of metagenome.

The study of microbial communities based on cultivation techniques highly depend on culture media. The problem is that soil as complex media for microbial growth in which they are interacting each other. Many progress have been obtained from cultivation-based methods, especially related to modification of nutrient culture media, such as by reducing nutrient component and concentration of culture media (Aagot et al. 2001; Connon and Giovanni 2002; Schoenborn et al. 2004), adding growth stimulant (Nichols et al. 2008; D'Onofrio et al. 2010), soil extract amended (Hamaki et al. 2005; O'Neill et al. 2009; George et al. 2011) plant juice supplemented (Stamer et al. 1970; Nour et al. 2010) and adding exudates of artificial root and root exudates (Baudoin et al. 2003; Kozdroj; Louvel et al. 2011 and van Elsas 2000). To date, no single media that can bring satisfaction for microbial cultivation.

Because of the facts that Lombok Island dryland will be developed for plantation of agricultural crops, especially maize, it is important to explore many aspects of culturable bacterial community of the dryland related to maize plantation. To cover greater bacterial isolate, this study improved modification of culture media by supplementing soil extract and root extract of maize on low nutrient concentration media. The goal of this study was to explain the contribution of dryland culturable bacterial community to give good growth performance of maize. Accordingly, this investigation examines the relation of maize growth performance with culturable bacterial community of their rhizosphere and the effect of culture media on number of bacterial isolates recovery.

\section{MATERIALS AND METHODS}

Soil Sampling. Four types of rhizosphere soil samples used in this study, namely Ktr50II, D50II, G50II, and A50II. The soil samples were collected from rhizosphere of two months age of maize (Zea mays var BISI 2) that grew in dryland field located at Lombok Island, West Nusa Tenggara, Indonesia (S $08^{\circ} 13^{\prime} 42.4^{\prime \prime}$, E $\left.116^{\circ} 21^{\prime} 24.4^{\prime \prime}\right)$. Study of soil samples continued in greenhouse experiment on the growth of maize for $30 \mathrm{~d}$. As a result, each soil sample application showed different vegetative growth performance of maize in greenhouse. D50II gave better growth performance of maize, A50II and Ktr50II gave worse growth performance, and G50II gave medium growth performance. Maize root mass were taken from the field and placed in plastic bags labeled. The rhizosphere soil samples were collected as described by Phillips and Fahey (2006). All soil samples were placed into sterile plastic bags labeled and stored in the refrigerator at $6-7^{\circ} \mathrm{C}$. 
Preparation of Culture Media. Rhizosphere bacteria were cultivated using commercial culture media (Soil Extract Agar) and non commercial modification culture media (NAln, NAln-SE and NAln-RE). Soil Extract Agar (SEA, HIMEDIA, Mumbai, India) consisted of $1 \mathrm{~g} \mathrm{~L}^{-1}$ glucose, dipotassium phosphate $0.50 \mathrm{~g} \mathrm{~L}^{-1}, \quad 17.75 \mathrm{~g} \mathrm{~L}^{-1}$ soil extract, and $15 \mathrm{~g} \mathrm{~L}^{-1}$ agar. Nutrient Agar low nutrient (NAln) consisted of $1 \%\left(0.08 \mathrm{~g} \mathrm{~L}^{-1}\right)$ Nutrient Broth (Criterion, Santa Maria, CA) and $18 \mathrm{~g} \mathrm{~L}^{-1}$ agar powder. Nutrient Agar low nutrient supplemented with soil extract (Naln-SE) consisted of NAln and $50 \%$ soil extract. Nutrient Agar low nutrient supplemented with root extract of maize (Naln-RE) consisted of NAln and $25 \%$ soil extract. On each medium, $50 \mu \mathrm{g} \mathrm{mL}^{-1}$ of antifungal nystatin was added.

Firstly, soil extract and root extract prepared. Soil extract was taken from soil in Lombok Island dryland. One part of soil sample was mixed with two parts of sterile water $(w / v)$. Soil slurry was sterilized for $1 \mathrm{~h}$ (O'Neill et al. 2009) and then allowed $24 \mathrm{~h}$ at room temperature. The supernatant was filtered with thick layer sterile cotton. The liquid of soil extract was stored at $6-7{ }^{\circ} \mathrm{C}$. The maize root extract was prepared from maize root mass (Zea mays var BISI 2). One part of the root mixed with two parts of sterile water $(w / v)$. Root slurry was sterilized for $20 \mathrm{~min}$ and then allowed $24 \mathrm{~h}$ at room temperature. The supernatant was filtered with thick layer sterile cotton. The liquid of soil extract was stored at $6-7^{\circ} \mathrm{C}$.

Cultivation and Growth Ability of Rhizosphere Soil Bacteria. Ten grams of soil samples were suspended in $90 \mathrm{~mL}$ of sterile saline $(0.85 \% \mathrm{NaCl})$. The soil suspension was shaken on a rotary shaker for 15 min. From dilutions $10^{-3}, 10^{-4}, 10^{-5}, 10^{-6}$, and $10^{-7}, 100 \mu \mathrm{L}$ aliquots of suspensions were spreaded on the surface of all of four culture media and incubated at $28{ }^{\circ} \mathrm{C}$ for 7 days. During incubation, total colony forming unit (CFU), number of bacterial isolates, and CFU of each isolate were determined. Cultural morphology, colony texture, colony pigmentation, and cell characteristics were recorded. The colonies were also streaked on each medium to verify their characteristic to avoid double identification. Interesting isolates were identificated based on size of Terminal Restriction Fragment (TRFs) of 16S rDNA were digested with the MSpI restriction enzyme. Purified bacterial isolates were stored in $20 \%$ glycerol at $-20^{\circ} \mathrm{C}$ for use throughout the study.
Antagonistic Assay. Some previous studies suggested that bacteria in mix culture could inhibit the growth of other bacteria by producing antibacterial substance. In this study, the bacterial isolates were also examined for their antagonistic ability to inhibit other isolates. The suspected of antagonist isolates were streaked on the edge of agar plate of all culture media and incubated at $28{ }^{\circ} \mathrm{C}$. Three days after incubation, tested isolates were streaked horizontally $5 \mathrm{~mm}$ in opposite to antagonist and further prolonged incubating for 2 weeks. Inhibition activity of antagonists were determined as the positive ability when the colony of testing isolates was retarded.

Statistical Analysis. Each treatment was made in 3 replicate. All result enumerations of isolates and colony were analyzed using Annova 5\% and then followed by using Turkey Method of minitab 16 .

\section{RESULTS}

\section{Abundance of Bacteria Isolated from Maize} Rhizosphere Soil. Thirty-four bacteria isolates were cultivated from four maize rhizosphere soil (Ktr50II, D50II, G50II, and A50II ) using four culture media (SEA, NAln, NAln-SE, and NAln-RE). The number and isolate types in each rhizosphere soil sample are showed in Fig 1 A. Number of isolate types were significantly higher in D50II and significantly lowest in Ktr50II. At least 17 of the 34 isolates (50\%) were found in D50II. A further 12 of 34 isolates (35.29\%) were found in A50II, nine of the 34 isolates $(26.47 \%)$ were found in G50II, and five of the 34 isolates $(14.70 \%)$ were found in Ktr50II. Based on bacterial isolates distribution of each soil sample, 18 of 34 isolates $(52.9 \%)$ were found in certain soil samples and the other found in more than one soil samples. Based on colony forming unit (CFU), the number of CFU was significantly higher in G50II $\left(13.05 \times 10^{7}\right)$ and then decreased from D50II $\left(5.07 \times 10^{7}\right)$, A50II $\left(1.87 \times 10^{7}\right)$, and $\operatorname{Ktr} 50 \mathrm{II}\left(1.25 \times 10^{7}\right)$ (Fig $\left.1 \mathrm{~B}\right)$.

Comparison of isolate abundance showed that each rhizosphere soil sample has different relative abundance pattern. D50II has the most abundance isolates and then decreasing from A50II, G50II, and Ktr50II (Fig 2). Each soil sample was inhabited by different dominat isolate type. For examples, CDL 30 is the most abundant isolate found in Ktr50II, CDL 38 found abundance in D50II, CDL 6 found abundance in G50II, and CDL 33 found abundance in A50II. Relative 
A

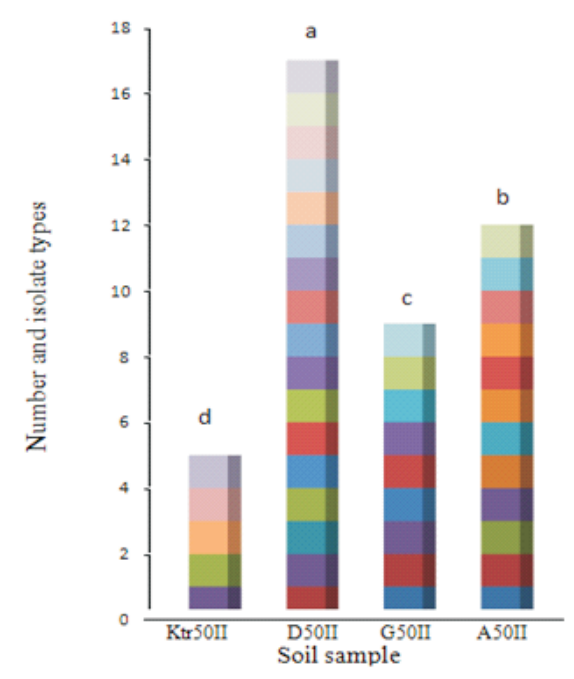

B

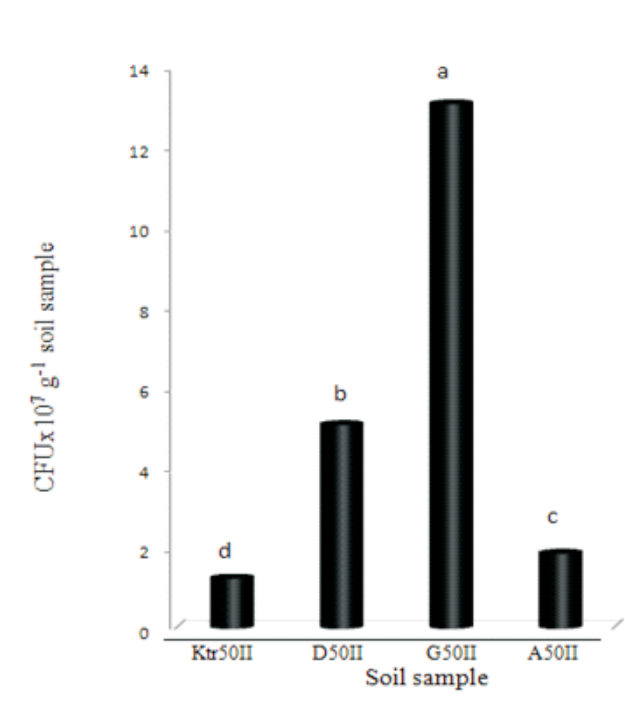

Fig 1 Comparison of number and isolate type (A) and colony forming unit (B) of maize rhizosphere bacteria cultivated from maize rhizosphere soil samples cultivated using four culture media (SEA, NAln, NAln-SE, and NAln-RE).
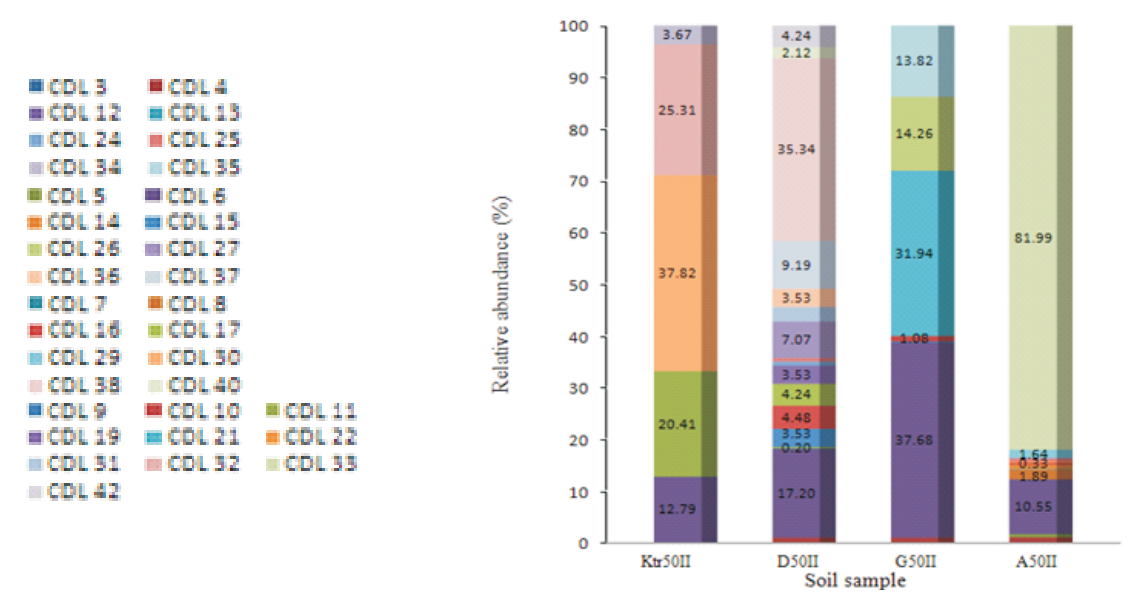

Fig 2 Estimation of relative abundance of maize rizosphere bacteria from Lombok Island dryland related to different growth performance of maize made by cultivation technique using four different culture media.

abundance of dominant isolate found in D50II showed not more than $35.34 \%$, while in the other soil samples more than $37.60 \%$. CDL 6 was detected as a predominant isolate was found in all soil samples. CDL 6 is known to having 123 TRF size digested with the MspI restriction enzyme.

Ability of Each Culture Media to Cultivate the Rhizosphere Bacteria. Fourteen of the 34 isolates were cultivated on NAln-RE, 12 of 34 isolates were cultivated on NAln, 11 of the 34 isolates were cultivated on Naln-SE, and 10 of the 34 isolates were cultivated on SEA (Fig 3). At least 5 isolate types shared cultivated on NAln, NAl-SE and NAln-RE, 6 isolate types shared on NAln-SE, and NAln-RE, while 7 isolate types shared on NAln, NAln-SE and NAlnRE. At least $29.4 \%$ of bacterial isolates were cultivated on SEA only while the remaining $(70.6 \%)$ were cultivated on NAln, NAln-SE, and NAln-RE. 


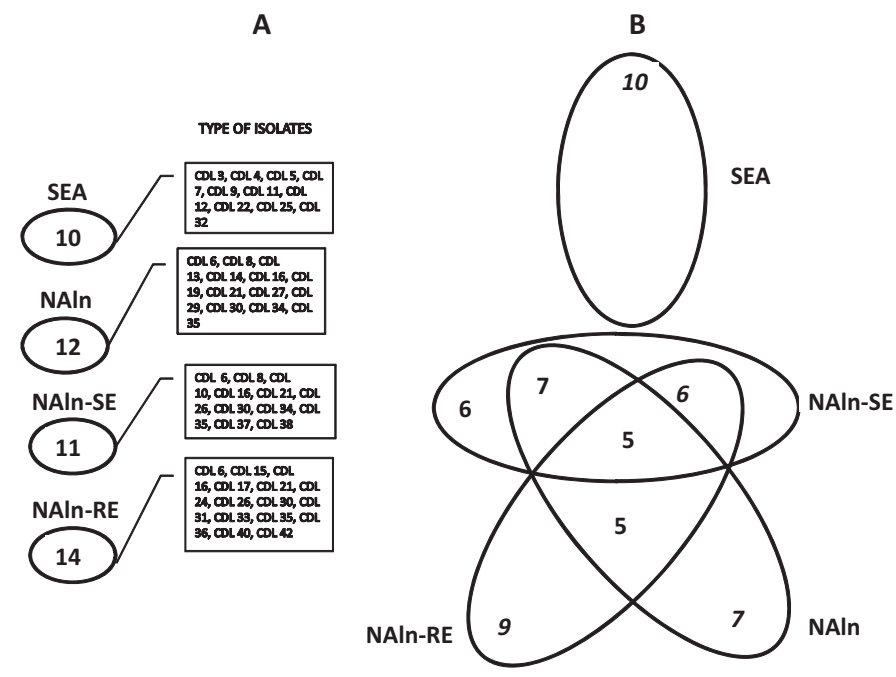

Fig 3 Comparison of number and isolate type isolated using four culture media (A) and number of isolate shared among culture media (B).

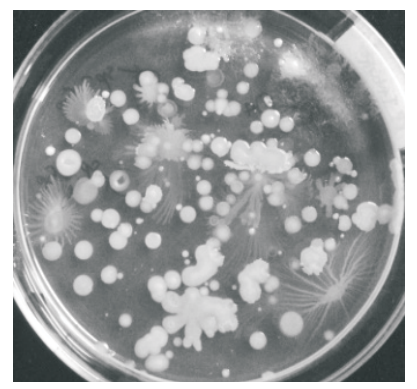

A

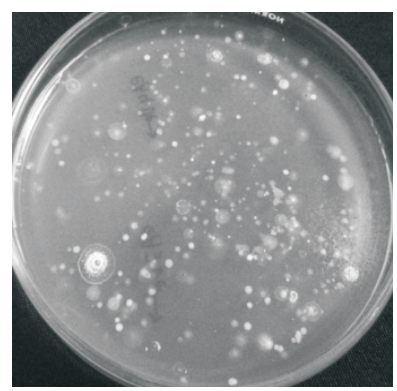

C

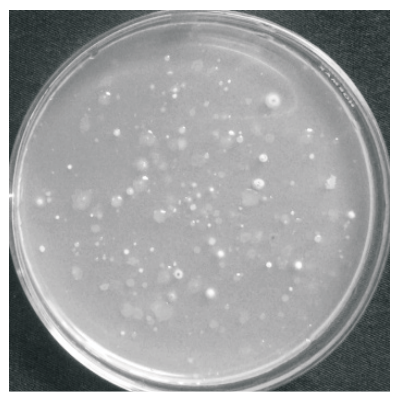

B

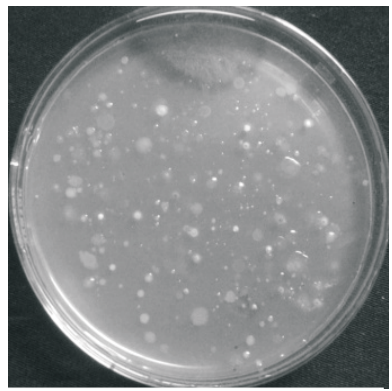

D

Fig 4 Appearance of colony development of maize rhizosphere bacteria on SEA (A), NAln (B), NAln-SE (C), and NAln-RE (D) at $10^{-3}$ dilution after 6 days of incubation.

Growth Differences of Bacterial Isolates on Each Culture Medium. Nearly all bacterial colonies developed on SEA have different morphological appearances compared with NAln, NAln-SE and NAln-RE (Fig 4). The bacterial colonies were cultivated on SEA developed during the first day of incubation. The characteristic of these colonies were as follows: fast growing, colony diameter average of 2.0 - $2.5 \mathrm{~mm}$ with clear differences among each colony morphology (Fig 4 A). When the dilution higher than $10^{5}$, only dominated with growing of certain isolates.
The growth of these isolates usually followed by appearance the yellowish color surrounding the colonies. Bacterial colonies were cultivated on NAln, NAln-RE, and NAln-SE developed after 3 days of incubation. The characteristic of the colonies were as follows: slow growing, colony diameter average of $0.5-2.0 \mathrm{~mm}$, and many of these are very thin and transparent (Fig 4 B, C, D). Cultivated bacteria from dilution higher than $10^{5}$ not showed phenomena such as on SEA. Physiological differences were also found only in six isolates such as CDL 12, CDL 19, CDL 25, 

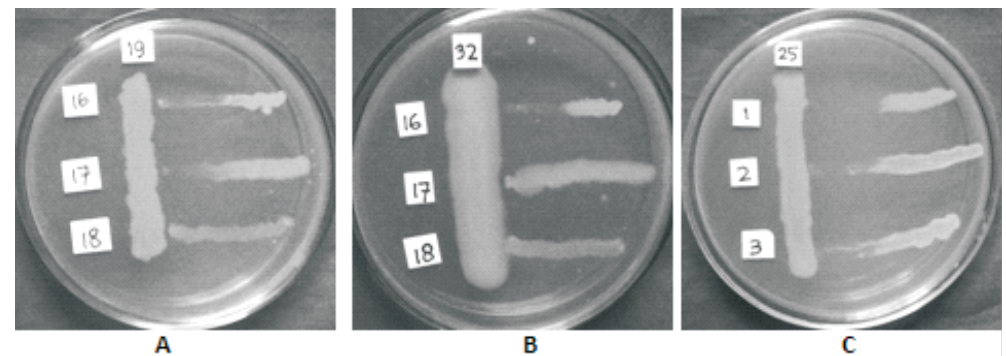

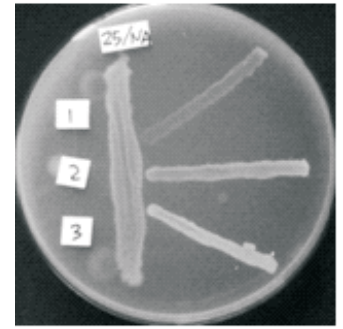

D

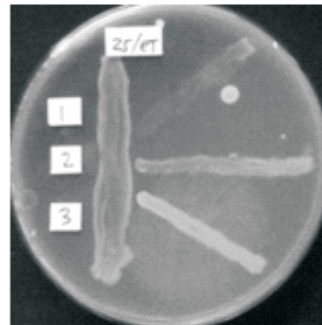

$\mathrm{E}$

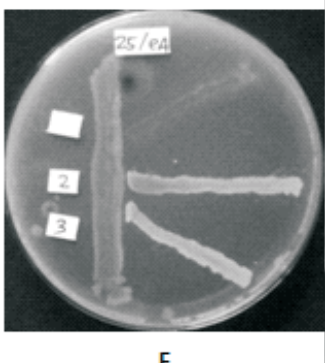

Fig 5 Bacterial antagonist (in vertical streak) isolated from maize rhizosphere soil bacteria. Antagonistic ability developed when grew on SEA (A, B, C) but not on NAln (D), NAln-SE (E), and NAln-RE (F).

CDL 26, CDL 30, and CDL 32, where those isolates produced yellowish color around the colonies when grew on SEA. This evidence did not happen when they grew on NAln, NAln-SE, and NAln-RE.

Antagonistic Ability in Some Bacterial Isolates. Antagonistic assay was done to six isolates (CDL 12, CDL 19, CDL 25, CDL 26, CDL 30, and CDL 32) that produced yellowish color when grew on SEA. This assay showed that ability to produce yellowish color is related to antagonistic ability of the isolates in inhibiting the growth of other isolates (Fig 5). The antagonistic ability only showed when the antagonist grew on SEA (Fig 5 A, B, C) and not on NAln, NAlnSE and NAln-RE (Fig 5 D, E, F). The antagonist inhibited the growth of certain isolates but not in other isolates.

The CDL 30 and CDL 32 were detected as the higher relative abundance in Ktr50II. CDL 30 known to having 486 TRF size and showed $98 \%$ score identity similar with Pseudomonas stutzeri (NR_114751), while CDL 32 known to having 485 TRF size and showed 97\% score identity similar with Pseudomonas pseudoalcaligenes (NR_037000). In the other soil samples, relative abundance of the antagonist less than $15 \%$.

\section{DISCUSSION}

This study is the first recorded of the maize rhizosphere bacterial states in Lombok Island dryland.
The results of this experiment showed that based on total number isolates and colony forming unit (CFU), D50II has higher number of bacterial isolates compared with other soil samples. Despite D50II has lower number of CFU compared with G50II, the number of CFU about $5.07 \times 10^{7}$ is more likely produced better growth. As for the G50II, although that soil sample has higher of CFU compared with D50II, less number of isolate likely it was not enough to produce better growth as D50II. Despite of A50II has higher number of isolates but less number of CFU may caused poor growth compared with G50II. In Ktr50II, lowest number of isolates and CFU may caused the worse growth. This result explained that the number of bacterial isolates more important to maize growth than total CFU. In addition, each kind of bacteria should be present in a sufficient number to be able to affect the growth of maize. The results indicated that the maize growth performance influenced by number and isolate type on the soil samples.

Although the number of isolate types in A50II significantly higher than G50II, but the community seemed to be dominated by only one type of isolate is CDL33, which the relative abundance about $81.99 \%$ (Fig 2). In addition to number of isolate type and CFU, the relative abundance pattern that composed each soil type may contribute to differentiation of the growth performance of maize. It predicted that more abundant baceria with balance composition should give better effect to maize growth. 
More previous study showed many aspects that known to influence the microbial community (Di Cello et al. 1997; Schmalenberger and Tebbe 2003; Dohrmann et al. 2013). In this study, when the influence of the abiotic factors and plant are reduced, it appeared that the rhizosphere bacterial community contributed to influence the growth of maize. It is assumed that abundance of the origin microbial status in dryland is the initial factor that influence the growth of maize.

The results also showed that $52.9 \%$ of bacterial isolates were found in certain soil sample and the other found on more than one soil samples. The similarity of isolate type was found in the soil samples may it is because of the soil samples taken from the same soil type from the same location. While the variation of isolate type was found in the soil samples may it is because of each soil sample has different origin microbial diversity since they are in the land. Furthermore, the differences of diversity which contributed to the differences of maize growth performance.

By doing variation in composition of media such as low concentration of nutrients (NAln), low concentration of nutrients supplemented by soil extract (NAln-SE) and supplemented by maize root extract (NAln-RE) increased the number of culturable bacteria obtained from the soil sample compared with commercial media only. It was suggested that the different nutrient composition is likely affected the number and type of bacterial cultivated on each media. In this experiment, rich nutrient composition of the SEA may provide conditions that allow for certain groups of bacteria to grow rapidly and dominate each other, while the slow growing bacteria will eliminated with no space to grow. In contrast to the NAln, NAlnSE and NAln-RE, poor nutrient composition provide conditions that allow the slow growing and dormant bacteria to grow. The similar results also found by other researcher (Brozel and Cloete 1992; Joseph et al. 2003).

The soil extract and root extract were supplemented to NAln-SE and NAln-RE respectively, may also contribute as a selection factor of the types of rhizosphere soil bacteria. According to Hamaki et al. (2005), soil bacteria and actinomycetes can grow on soil extract agar media but not on conventional media. Some experiments also showed that medium of soil extract amended was suitable for growth of fastidious soil bacteria (Davis et al. 2005) and also reduce diversity and dominance of fast growing bacteria (Kozdroj and van Elsas 2000).

According to Tamaki et al. (2005), bacteria in mix culture can produced antibacterial substances to inhibit the growth of other bacteria. Dominance also contributed to the ability of organisms to produce extracellular antibacterial component (Rao et al. 2005). Refer to Tamaki et al. (2005) and Rao et al. (2005), it is likely that the antagonistic ability of six isolates (CDL 12, CDL 19, CDL 25, CDL 26, CDL 30, and CDL 32) may caused by antibacterial substances that produced by the isolates. The antagonistic ability of these rhizosphere soil bacteria not only when they are in the form of mixed cultures but also explained the relationship between type of culture media and antagonistic ability of the bacteria.This antagonistic mechanism may one of the factor causing fewer number of cultivated bacteria and lower total CFU of bacteria on SEA.

\section{REFERENCES}

Aagot N, Nybroe O, Nielsen P, Johnsen K. 2001. An altered Pseudomonas diversity is recovered from soil by using nutrient-poor pseudomonas-selective soil extract media. Appl Environ Microbiol. 67(11): 5233-5239. doi:10.1128/AEM.67.11.5233-5239.2001.

[BAPPEDA] 2003. Strategic plan for the development of dryland regions of NTB Province 2003-2007.

Baudoin E, Benizri E, Guckert A. 2003. Impact of artificial root exudates on the bacterial community structure in bulk soil and maize rhizosphere. Soil Biol Biochem. 35: 1183-1192. doi:10.1016/S0038-0717(03)00179-2.

Brozel VS, Cloete TE. 1992. Evaluation of nutrient agars for the enumeration of viable aerobic heterotrophs in colling water. Wat Res. 26(8):1111-1117. doi:10.1016/ 0043-1354(92)90148-W.

Castellanos T, Dohrmann AB, Imfeld G, Baumgarte S, Tebbe CC. 2009. Search of environmental descriptors to explain the variability of the bacterial diversity from maize rhizospheres across a regional scale. Eur J Soil Biol. 45:383-393. doi:10.1016/j.ejsobi.2009.07.006

Connon SA, Giovanni SJ. 2002. High-throughput $\mathrm{m}$ for culturing microorganisms in very-low-nutrient media yield diverse new marine isolates. Appl Environ Microbiol. 68(8): 3878-3885. doi: 10.1128/AEM.68.8. 3878-3885.2002.

Davis KE, Joseph SJ, Jansen PH. 2005. Effects of growth medium, inoculums size, and incubation time on culturability and isolation of soil bacteria. Appl Environ Microbiol. 71 (2): 826-834. doi: 10.1128/AEM.71.2. 826-834.2005

Di Cello F, Bevivino A, Chiarini L, Fani R, Paffetti D, Tabacchioni S, Dalmastri C. 1997. Biodiversity of a 
Burkholderia cepacia population isolated from the maize rhizosphere at different plant growth stages. Appl Environ Microbiol. 63(11): 4485-93.

D'Onofrio A, Crawford JM, Stewart EJ, Witt K, Gavrish E, Epstein S, Clardy J, Lewis K. 2010. Siderophores from neighboring organisms promote the growth of uncultured bacteria. Chem Biol. 17(3): 254-64. doi:10.1016/j.chembiol.2010.02.010.

Dohrmann AB, Küting M, Jünemann S, Jaenicke S, Schlüter A, Tebbe CC. 2013. Importance of rare taxa for bacterial diversity in the rhizosphere of Bt- and conventional maize varietie. The ISME Journal 7:3749. doi:10.1038/ismej.2012.77.

George IF, Hartmann M, Liles MR, Agathos SN. 2011. Recovery of as-yet-uncultured soil Acidobacteria on dilute soil media. Appl Environ Microbiol. 77(22): 8184-8188. doi:10.1128/AEM.05956-11.

Hamaki T, Suzuki M, Fudou R, Jojima Y, Kajiura T, Tabuchi A, Sen K, Shibai H. 2005. Isolation of novel bacteria and actinomycetes using soil-extract agar medium. J Biosci Bioeng. 99(5): 485-492. doi: 10.1263/jbb.99. 485.

Joseph SJ, Hugenholtz P, Sangwan P, Osborne CA, Janssen PH. 2003. Laboratory cultivation of widespread and previously uncultured sail bacteria. Appl Environ Microbiol. 69 (12): 7210-7215. doi: 10.1128/AEM.69. 12.7210-7215.2003.

Kozdroj J, van Elsas JD. 2000. Response of the bacterial community to root exudates in soil polluted with heavy metals assessed by molecular and cultural approaches. Soil Biol Biochem. 32: 1405-1417.

Li X, Rui J, Mao Y, Yannarell A, Mackie R. 2014. Dynamics of the bacterial community structure in the rhizosphere of a maize cultivar. Soil Biol Biochem 68 (2014) 392401.

Louvel B, Cébron A, Leyval C. 2011. Root exudates affect phenanthrene biodegradation, bacterial community and functional gene expression in sand microcosms. Int Biodeter Biodegr. 65: 947-953. doi:10.1016/j. ibiod.2011.07.003.

Nichols D, Lewis K, Orjala J, Mo S, Ortenberg R, O'Connor P, Zhao C, Vouros P, Kaeberlein T, Epstein SS. 2008.
Short peptide induces an "uncultivable" microorganism to grow in vitro. Appl Environ Microbiol. 74(15): 4889-4897. doi:10.1128/AEM. 00393-08.

Nour EH, Hamza MA, Fayez M, Monib M, Ruppel S, Hegazi NA. 2010. The crude plant juices of desert plants as appropriate culture media for the cultivation of rhizospheric microorganisms. J Adv Res. 3: 35-43. doi:10.1016/j.jare.2011.03.002.

O'Neill B, Grossman J, Tsai MT, Gomes JE, Lehmann J, Peterson J, Neves E, Thies JE. 2009. Bacterial community composition in brazilian anthrosol and adjacent soils characterized using culturing and molecular identification. Microb Ecol. 58(1): 23-35. doi:10.1007/s00248-009-9515-y.

Pham VHT, Kim J. 2012. Cultivation of unculturable soil bacteria. Trends in Biotechnol. 30(9): 475-484.

Phillips RP, Fahey TJ. 2006. Tree species and mycorrhizal associations influence the magnitude of rhizosphere effects. Ecology 87(5): 1302-1313.

Rao D, Webb JS, Kjelleberg S. 2005. Competitive interactions in mixed-species biofilms containing the marine bacterium Pseudoalteromonas tunicate. Appl Environ Microbiol. 71(4): 1729-1736. doi: 10.1128/AEM.71.4.1729-1736.2005.

Reid A, Buckley M. 2011. The Rare Biosphere: A report from the American Academy of Microbiology. Washington, DC 20036. p 1-28.

[RENSTRA] 2009. Strategic Plan of the Ministry of Agriculture 2010-2014.

Schmalenberger A, Tebbe CC. 2003. Bacterial diversity in maize rhizospheres: conclusions on the use of genetic profiles based on PCR-amplified partial small subunit rRNA genes in ecological studies. Mol Ecol. 12(1): 51-262. doi: 10.1046/j.1365-294X.2003. 01716.x.

Zhang X, Ma L, Gilliam FS, Wanga Q, Li C. 2013. Effects of raised-bed planting for enhanced summer maize yield on rhizosphere soil microbial functional groups and enzyme activity in Henan Province, China. Field Crops Res. 130: 28-37. doi:10.1016/ j.fcr.2012.02.008. 